\title{
Technologizing the Divine
}

\section{Peter McLaren ${ }^{1,2}$}

Published online: 6 September 2019

(C) Springer Nature Switzerland AG 2019

5 Now listen, you rich people, weep and wail because of the misery that is coming on you. 2 Your wealth has rotted, and moths have eaten your clothes. $\mathbf{3}$ Your gold and silver are corroded. Their corrosion will testify against you and eat your flesh like fire. You have hoarded wealth in the last days. 4 Look! The wages you failed to pay the workers who mowed your fields are crying out against you. The cries of the harvesters have reached the ears of the Lord Almighty. 5 You have lived on earth in luxury and self-indulgence. You have fattened yourselves in the day of slaughter.[a] 6 You have condemned and murdered the innocent one, who was not opposing you. (James 5:1-6)

Technology has helped us to define who we are as a species. But for all of its potential for good, it has wrought a malignant vengeance, calumniating the poor as disposable wastrels and inducing all but the owners of the means of production to endure many species of alienation. An intemperate obstacle arises when we attempt to technologize human spirituality. The ultimate apocalyptic vision of a technologized, multitasking God is epitomized in Ezekiel's thundering theophany, which depicts a chariot of fire (described by Milton as a Chariot of Paternal Deitie), a whirl-a-gig-tilt-a-whirlAstroland image of wheels rotating inside wheels, eyes shifting back and forth inside eyes shifting back and forth, visions inside visions, the loins of God set aflame, seers being seen, descriptions of the indescribable, the unknown clamoring to become known. Wheels always moving in unison with winged beings.

The vision of a machine-like cybernetic God, a technological apparatus of spirit and matter forged into a flying vehicle that teleported Ezekiel from the Chebar Canal, to the courtyard of the Jerusalem Temple, and back to Babylon-was a precursor to the modern divinization of technology. To say as much is to risk being misunderstood as a postdigital false prophet or steampunked blasphemer, neither of which seems very

Peter McLaren

peter.mclaren1@gmail.com

1 Chapman University, Orange, USA

2 Northeast Normal University, Changchun, China 
appealing. Nevertheless, could this visio Dei of Ezekiel have foreshadowed the terrifyingly combustible link between technology and the divine? In this vision, technology becomes a fierce attribute of divinity, and in the hands of men and false prophets, it could easily entice mere mortals to employ technology in the service of wealth and power - or world domination. Just think of the V-2 buzzbombs of Hitler reigning down on stalwart Londoners. Does such a vision of Ezekiel pertain solely to a flying chariot, or could it represent a Snowpiercer-like locomotive, a fighter jet, an unidentified flying object from a distant solar system, a nuclear missile? Does the return of the chariot in chapter 8, transporting Ezekiel to Jerusalem, and then back to Babylonia, indicate a transcendent warning? Is it a harbinger of the 'end times', of Armageddon (Lieb 1998), a warning from Klaatu (from the movie, The Day the Earth Stood Still (Derrickson 2008))? Is this the work of a cosmic Hal, the computer (from Kubrick's 2001 (1968)), the triumph of techne over mystery? Have we misused technology, offended God in our overreach by technologizing that which must remain unnamed? Will the hateful altright meme of Pepe the Frog circling throughout cyberspace, transport the Gog of Magog to the North in preparation for an end times showdown at the OK Corral located inside the black hole in the Milky Way? Have we exonerated Dr. Frankenstein, have we put aside the lessons of the Holocaust and reinscribed the dangers of technology in our nuclear capabilities and reconfigured them in our plans to weaponize outer space and colonize its outer limits? Have we violated the interdictions of the Merkabah and Hekhalot by tarrying with the psychogenetic foundations of technomorphosis, as Lieb (1998) suggests?

Heeding the vision of Ezekiel are those fundamentalist Christians that are so sure that the end is near that they will throw environmental concerns into the wind, fracking the last bit of oil out of the tar sands while they wait for the four horsemen to begin their divine giddayap across the firmament. Is Ezekiel's fiery vision a warning that Jerry Falwell Jr. or Franklin Graham will be in the saddle with Christ and the saints? If so, do we need to align ourselves with the remnants of the Tea Party in order to be saved? Or is Falwell, perhaps, the Gog of Magog? Will Franklin Graham replace Saint Peter and form an angelic division of ICE, preventing that shining city on a hill from being contaminated by the sub-human 'infestation' of people of color, those 'rapists' and criminals from America Latina, those 'snakes' from Syria, those black people that come from 'shithole' countries in Africa, those 'treasonous' critics of Trump, those 'enemies of the people' otherwise known as journalists, and those hateful ingrates from 'The Squad' who refuse to 'go back' to the 'crime infested places from which they came.' What powers the machines - faces genetically engineered? Will Emma Goldman and Alexander Berkman arise from their graves, strip and blindfold Trump while Big Bill Haywood covers him with molasses and feathers? A resurrected Frank Little might want in on some of the action. Perhaps when Trump is cast into the fiery pit, the spoked chariot will spin its way through the heavens to Outpost Nine and unload its motley crew of starship troopers: Phineas Quimby, Norman Vincent Peale and Father Yod. And we will not see it again until the next tyrant arises from the ashes of Trumpland, and Ezekiel sounds his final warning - an eschatological warning, perhaps, of yet another mass extinction. Or will the chariot reappear as a vehicle of redemption and liberation as in 'swing low sweet chariot, coming for to carry me home.' 'Train coming oh let me ride... Oh low down the chariot and let me ride.' Does this transfigurational spiritual refer perhaps to the underground railroad - to a vehicle of 
liberation concretized as a train (Leib 1998)? Or will it be carrying the Master of Intrigue preparing for apocalyptic combat against God's coalition of white supremacists led by Vice President Mike Pence? It's common knowledge that Reagan yearned for Armageddon. Did he not in invite the religious demagogue Jerry Falwell to National Security Council briefings? The advance of communism, for Reagan, was the mighty index of the closeness we are to the fire and brimstone of Armageddon. The Gipper longed to create in the heavens the Strategic Defense Initiative, an aeronautically sophisticated network of space-based X-ray lasers to incinerate any incoming nuclear ballistic missiles that dared to be launched by the dirty reds, a maneuver coordinated perhaps with Ezekiel's great Chariot of Fire. Of course that was a time before the repo man struck and hauled the Chariot away to a scrap metal yard in the Mojave Desert. There it was transformed into a chopped, channeled and sectioned 1964 Chevrolet Malibu powered by a Quantum Vacuum (Zero Point) Electromagnetic Generator. And now it's the favored mode of transportation of The Unholy Trinity - the Lord of Science, the Minister of Paradox, and leaders of the Christian Resistance Movement, who have been advised by the US military on the methods of shock and awe (in a manner similar to those Toyota Hilux light pickup trucks with heavy weaponry mounted in the bed became the favored mode of transport of Islamic State.

We need to worry about weaponizing the divine, of using stochastic terrorism (employing mass media to encourage terrorist acts) to incite those cult members who worship at the altar of the God of Chaos, aka Donald Trump. It's bad enough when we learn from the UN Assistance Mission in Afghanistan that more civilians were killed by the US and allied forces than by the Taliban and other terrorist organizations during the first half of 2019. But what about innocents on American soil? What motivates Trumpinspired men such as Cesar Sayoc, Scott Leader, Steve Leader, Curtis Allen, Gavin Wright, Patrick Eugene Stein, Alexandre Bissonnette, Michael Hari, Michael McWhorter, Joe Morris, James Alex Fields Jr., Brandon Griesemer, Nikolas Cruz, and Patrick Crusius? I think we know. And it is not simply the love of video games. A Washington Post study reports that in counties that hosted a Trump rally in 2016 saw a $226 \%$ increase in hate crimes (Sakuma 2019). The Anti-Defamation League also reports that extremist related murders increased 35\% from 2017 to 2018 (Pitcavage 2019).

Much has been said about the stereophonic nationalism associated with Trump's base. But we forget at our peril those Trump supporters whose psyches have been bludgeoned into silence by rhetorical overkill, who exhibit symptoms of what I call cataleptic nationalism, a trance-like state of consciousness that resembles the catatonic condition that occurs with some forms of schizophrenia in which individuals have lost voluntary motion, where individual agency has been plowed and harrowed into oblivion, where protagonistic volition has been hallowed out by the swindle of Trump's tyranny, such that Trump followers simply nod and follow silently in the wake of their more rambunctious counterparts, although they appear shorn of the belligerence and toxic affect that we have come to expect of Trump supporters. Here they fall prey to faux-intellectuals such as Dinesh D'Souza, who compares liberal Democrats to Nazi brownshirts. Perhaps this ideological distortion is to be expected in a world whose governments are run by the likes of the repugnant Jair Bolsonaro, Joseph Kabila, Pierre Nkurunziza, Recep Tayyip Erdogan, Abdel Fattah al-Sisi, Rodrigo Duterte, Benjamin Netanyahu, Viktor Orban, Jaroslaw Kaczynski, Matteo Salvini, Narendra Modi, Hun 
Sen, Andrej Babis, Jimmy Morales, Aung San Suu Kyi (what is going on with her?), Mohamed bin Salman, Vladimir Putin, Donald Trump, and so many other autocrats, fascists, and human rights violators.

It appears that the world around us is in tatters. Right wing movements are growing in the USA; supporters of the lunatic QAnon and Pizzagate conspiracies mix with flatearthers, neo-Nazis and white supremacist ethno-nationalists such as Richard Spencer, Turning Point USA activists, the horrid likes of Fox News personalities Tomi Lahren, Ben Shapiro, Tucker Carlson, Sean Hannity, Laura Ingraham-and this mix of reactionary hatred has created a toxic American zeitgeist. Sooner or later a white supremacist message reaches like the five fingers of death into the laptop of some young deranged white youth who then unloads his assault rifle into a crowd of innocents. Mass shootings are becoming commonplace throughout the USA while Trump mocks a black Congressman whose house was burglarized, he praises himself and Kim Jong Un in an insane tweet:

Chariman Kim has a great and beautiful vision for his country, and only the United States, with me as President, can make that vision come true. He will do the right thing because he is far too smart not to, and he does not want to disappoint his friend, President Trump! ${ }^{1}$

Trump is not the only white supremacist to have occupied the White House. Nixon believed that whites were at the pinnacle of the racial hierarchy and that African-Americans and Latino/as were at the bottom. He referred to Africans as cannibals. Reagan referred to Africans as monkeys (Naftali 2019). Trump has referred to Latino/as criminals, rapists, and drug dealers and described Africans as coming from 'shithole' countries. This is quite illuminating in light of the fact that Trump himself allegedly committed rape, if we are to believe his accuser, a respected journalist (BBC News 2019) whom Trump described as 'not my type' (Baker and Vigdor 2019). And would it surprise many of us if it were to be discovered that Trump's businesses have been involved in serious criminal activity? His attacks on the primarily black city of Baltimore, Congresswomen of color, Congressman Elijah Cummings, media personality Don Lemon, reveal that Trump and his defenders do not understand the phenomenon of racism. In schools of education, we teach courses on critical multiculturalism and study the socio-historical, ideological, and semiotic dimensions of racism, the intersections of race, class, gender, sexuality - from micro-aggressions to the role capitalism plays in generating racism - and the psychological dynamics of racism when racism takes on a life of its own, as it has throughout the USA. Obviously, this work has not filtered through to the general population in the USA, especially among Republicans who support Trump. They need to study the works of Frantz Fanon. And while we condemn the heinous slaughter of the Jews by the Nazis, we must recognize that the destruction of the indigenous populations throughout the Americas was certainly the largest act of genocide in world history. In fact, the genocide perpetrated upon the indigenous peoples in the USA was one of the founding acts of this country.

\footnotetext{
${ }^{1}$ Donald Trump’s Twitter@realDonaldTrump, 2 August 2019, 05:05 PM.
} 
But young people are rising up, and those of my generation, too, whose family members fought the Nazis and fascists on the battlefields of Europe-we remember and will not fall for hatred's swindle of fulfillment. And some of us have found liberation theology to be helpful in finding religious faith, and faith in humanity, through social justice activism. Such activism is quietly monitored in this era of information investment - what Shoshana Zuboff (2019) calls 'surveillance capitalism'. Today's 'smart' and 'connected' information technology is used both in commercial and law enforcement surveillance. We are talking about not only federal law enforcement agencies such as the FBI, who would love to discover the ultimate 'radicalism algorithm' (Zuboff 2019), but also local police. For instance, information from a 'smart' utility device, and an iPhone 6s Plus and audio files captured by an Amazon Echo device succeeded in identifying a police suspect (Zuboff 2019). Information extracted from a Fitbit wristband was used in a personal injury case while an individual was charged with arson on the basis of data taken from his pacemaker. Surveillance-asa service companies are able to sell their technology to local police departments. GoFeedia specializes in keeping track of protesters and activists such as Greenpeace and union activists. GoFeedia also specializes in computing individualized 'threat scores' using data from social media (Zuboff 2019). Another company, Palantir, was found to have a secret relationship with the New Orleans Police Department with respect to testing 'predictive policing technology'. Such technologies are designed to predict whether you are likely to be a victim of a crime or a perpetrator - all based on your social media history (Zuboff 2019).

The Catholic Church has always played socially reproductive role in the history of capitalism, as have most churches, regardless of their denomination. In this particular dispensation, we can understand why, in 1843, Marx criticized religion as the opium of the people in his 'A Contribution to the Critique of Hegel's Philosophy of Right' when he wrote: 'Religion is the sigh of the oppressed creature, the heart of a heartless world, and the soul of soulless conditions. It is the opium of the people' (Marx 1843). Given the clericalism of the church-based leadership during the time of Marx, it certainly made sense for many to identify as atheists. In fact today, with the sex abuse crisis in the Catholic Church as extensive as it is, there is cause to believe clericalism today still performs a perfidious function (Sadowski 2019). But there is a mighty tributary of Catholicism known as liberation theology that has since the early sixties retained a reputation of steadfast social justice work on behalf of the poor and the oppressed. Just to be clear, not all liberation theology stems from the Roman Catholic Church as there were dialogues began between respected Catholic theologians that included Gustavo Gutiérrez, Segundo Galilea, Juan Luis Segundo, Lucio Gera, and well-known Protestant theologians Emilio Castro, Julio de Santa Ana, Rubem Alves, José Míguez Bonino, and others. The orthopraxis of priests, and not the clericalism of the Catholic Church, has been the mighty fortress of many-especially oppressed and exploited campesinos in America Latina who found refuge in the work of priests and bishops influenced by liberation theology. Enthusiasm among the poor and disenfranchised for liberation theology heightened at a time when campesinosand also liberation theologians - were being slaughtered by fascist death squads trained in the USA at Fort Benning, Georgia, then home of the infamous US Army School of the Americas (renamed the Western Hemisphere Institute for Security Cooperation). 
The Latin American Episcopal Conference (consisting of Roman Catholic bishops in Latin America), did impact the Second Vatican Council (1962-1965) into a more progressive position but Pope Paul VI did what he could to put the lights out on the burgeoning idea of liberation theology, whose birth pangs caused a chill in the ranks of Vatican officials, especially after the conference in Medellin, Colombia, in 1968, and in Puebla, Mexico in 1979. Despite efforts of the General Secretary of CELAM, Cardinal Alfonso Lopez Trujillo, who was to become Pope John Paul 11's pit bull, trying to put a stop to a theology that threatened the conservative catechesis of the Church, and the orthodox position taken by the Roman Curia, and efforts by Cardinal Ratzinger (later to become Pope Benedict XVI) liberation theology was to survive (McLaren and Jandrić 2017, 2018a, b).

Indeed, Pope John Paul II admonished the idea that Christ should become a political figure. And of course, he also affirmed the principle of private property, which is one of the foundations of capitalism. No surprise there, especially for a Pontiff who was raised during the communist regime in Poland and who was understandably anti-communist, and who, like so many conservative Catholics, mistakenly thought a theology partly inspired by Marx's critique of political economy must be inherently pro-Soviet Union (this is a problem with many who are virulently anti-communist and who have never read Marx's writings themselves and thus fail to understand Marx's humanism, relying instead on existing stereotypical readings of Marx emanating from the ashes of Cold War debates). True, some priests served as chaplains with Marxist guerrillas in Honduras, El Salvador, and elsewhere, but this hardly made them a threat to democracydespite Reagan's discredited 'falling domino' principle (that was first articulated by Eisenhower in relation to Vietnam) that Reagan applied to Latin America: that the Sandinista Revolution could start a communist 'domino effect' right up to the southern US border. For some liberation theologians, liberation theology means communion, not communism. And for others, better acquainted with Marx's writings, Marx's idea of communism is very different from that envisioned by those architects of the totalitarian dictatorships and state capitalist police states that claimed to be Marxists and who liked to pose in their oversized gray suits, pounding tables with their puffy fists under banners festooned with images of Marx, Engels, Lenin, and Uncle Joe.

There is no denying that the persecution of liberation theology was relentless. Who could forget Bolivia's Banzer Plan (created in collaboration with the CIA) or the role of Opus Dei in Chile throughout the 1970s? And who could forget the iconic image of John Paul II scolding Nicaraguan priest, Ernesto Cardenal, on the tarp at the Managua airport, or later during his visit to Nicaragua shaking his pastoral staff at those chanting 'popular power' and 'we want peace' during an open-air mass? I was so pleased to be seated next to Ernesto Cardenal during a talk by President Hugo Chavez at his weekly broadcast of Alo Presidente! (the location of which was kept secret until just hours before Chavez spoke because there are as many blood-thirsty right wingers in Venezeuela as there are here in the USA) and learning very recently that Pope John Paul II's 1984 suspension of Cardenal a divinis (because of Cardenal's refusal to leave his political office), has been lifted (in 2019) by Pope Francis. And while Ronald Reagan conspired to put an end to liberation theology, courtesy of the US military and CIA funding of conservative priests and bishops, some of whom became accomplices in CIA covert missions that saw nuns and clergy arrested, tortured, or killed (McLaren 2015), the USA and its allies were unable to silence those who believe it is their duty as 
Christians to challenge the structural sin of capitalism. I am referring here not only to those Christians who have been influenced by Freire, Gutierrez, Rahner, Moltmann, Ellacuría, Sobrino, Boff, and Porfirio Miranda, but by the actions of the poor to liberate themselves.

Who can forget the Jesuits murdered on November 16, 1989, by US-trained commandos of the Salvadoran armed forces at the Universidad Centroamericana (UCA), murdered along with the wife of a caretaker at the university, and her daughter? Who can forget the names Ignacio Ellacuría, Segundo Montes, Ignacio Martín-Baró, Juan Ramón Moreno, Armando López, Joaquín López y López, Julia Elba Ramos, and her daughter, Celina? We forget at our peril these Jesuanic martyrs and Sobrino's theological move 'De una teología sólo de la liberation a una teología del martirio' ('From a Theology Merely of Liberation to a Theology of Martyrdom.') After all, as Sobrino notes:

reality is known - in this case oppression and liberation, suffering and hope - in the disposition of taking charge of these realities in a praxis (en la disposicio?n a encargarse de ellas en una praxis), to carry these realities (a cargar con ellas)_running risks and the persecution that reality generates - and shouldering the weight of these realities (dejándose cargar por ellas) — accepting gratefully the kindness, generosity, and solidarity that there is in reality, and above all in the underside of history Drexler-Dreiś (2013).

How happy were those prosperity-gospel, praise-the-Lord, fire-and-brimstone preaching protestant evangelicals when they received financial support from the USA to broadcast their missions throughout Latin America? And while one of the foundational positions is that poverty results from the sin of greed, not the social relations and forces of production (I think it's both), Biblical scriptures clearly denounce greed as the primary sin that engenders poverty, and in so doing stipulates that poverty be abolished. Dorothy Day and the Catholic Worker Movement took up the charge, emphasizing action over doctrine - what those of us in critical pedagogy movement refer to as 'praxis' - and this term is very closely aligned with the revolutionary praxis of Marx. Knowing that it is our duty as Christians to fight poverty, we strive to participate in orthopraxis. Here there exists a dialectical relationship between orthodoxy and praxisdoing God's work (orthodoxy), which, in effect, is fighting capitalist exploitation (praxis). Clearly, from what I witnessed with the AbahlalibaseMjondolo in Durban, South Africa, and the Landless Workers' Movement in Brazil, and among community initiatives throughout North and South America who have been influenced by the teachings of Paulo Freire, social justice - meaning economic justice-enjoys primacy of purpose in the spiritual wheelhouse of its organizers.

Capitalism also drives racism, and racism then takes on a life of its own. In 2015, I spoke with Bishop Obispo in La Rioja, Argentina, about Pope Francis, and he described Francis as having sympathy with what he termed the 'theology of the people'-a liberation theology shorn of any Marxist ideology or armed revolutionary currents. He could have been referring to the Colombian priest, Camilo Torres, who was part of the guerilla group, ELN. Others I have spoken to have said that Francis is not supportive of liberation theology. However, Francis at the very least appreciates liberation theology's preferential option for the poor (I wish it had initially been announced as a preferential 
'obligation' to the poor), since he has made so secret of being an admirer of Rutilio Grande, a Salvadorean priest, and friend of Archbishop Oscar Romero (now Saint Romero) gunned down by a death squad. Romero himself was gunned down while celebrating the mass by a rightwing assassin. A Black Theology of Liberation has now a strong presence in African American communities, and we have strong proponents of feminist theology, postcolonial theology, reconciliation theology, and arising from the inner cities other social justice movements that have been influenced by liberation theology are everywhere in evidence (McLaren 2015).

Christian denominations have provided places for spiritual and political refuge, thanks to the influence of liberation theology. We are no longer condemned to the prosperity gospel of Joel Osteen's Las Vegas-meets-Galilee megachurch performances, where all of Christ's glory can be reflected in the sparkling sheen of Osteen's teethoverlaid in a smile that stretches for eternity. Put in more down-to-earth terminology, a smile that rivals the combined enamel of Marie Osmond's powerhouse pearly whites and Tom Cruise's infectious canines. We make no truck with 'the happy preacher.' No longer do we long for the days of Jim and Tammy Faye Bakker's Heritage USA, complete with a fairy tale 'King's castle', festive arcades and go-cart tracks and 'Jerry's Slide,' a 163-ft water slide that Jerry Falwell slid down in wearing his shiny suit, proudly brandishing his black suspenders and red tie as he emerged from the bubbling broth below, re-baptized in Disney-like splendor. Nor do we wish to visit Ark Encounter, the $\$ 100$ million Noah's Ark theme park in Kentucky or the 75,000-square-foot Creation Museum.

You would think that an astute reader of the Bible and a professed Christian would be wise to the scam of tithing and would be eager to be affiliated with churches that don't make the ludicrous claim that 'nowhere in the Bible does it say that the apostles were poor,' or that don't stipulate sending Pastor Creflo Dollar and Leroy Thompson money for their lavish lifestyles, or don't require 'releasing your faith' (i.e., giving your hard-earned cash) for a 'hundred-fold increase' in your material investments, or emptying your pockets so that,God will 'balance your spiritual books' in your favor because you didn't have a good childhood, weren't born with good looks, or didn't develop an infectious bubbly personality. Social justice doesn't require handing over your pocketbook to Robert Tilton, or planting your seed for a supernatural 'payback' harvest by purchasing a lottery ticket from Paula White. It doesn't require pledging fealty to Trump, or calling for parades showcasing the latest Pentagon weaponry. Or standing for the Pledge of Allegiance. Or attempting to overthrow the Venezuelan government. Or, in fact, meddling in the elections of sovereign nations (which the USA has done since the end of World War II). It requires a fight for truth, for liberty, for freedom. A struggle waged not under the banner of a prideful bellicism or what Albert Einstein (in Viereck 1929) called the 'infantile disease' of nationalism - the 'measles of mankind.' But in the pursuit of a critical patriotism - and atheists are welcome! Mr. Hobbes, are you listening? Your greatest fear has been realized in the wealthiest and most powerful of all existing democracies. Bellum omnium contra omnes, isn't it Mr. Hobbes? Our social contract has contracted a perfidious virus named Trump. The great whale is not white, Mr. Melville, it is orange, and it lives in the White House. The empire of liberty is our hubris as a citizenry. But the blame cannot be put on Trump's shoulders. The road to Trump has been paved for centuries by the white supremacist fear of the freedom of people of color and the social structures that enable predatory 
capitalism, and the toxic ideology that percolates from conservative media that socialism is somehow a free ride for the lazy. The US military currently operates in at least $40 \%$ of the world's countries (Savell and 5W Infographics 2019) and is currently at war in seven countries - in Afghanistan, Iraq, Syria, Yemen, Somalia, Libya, and Niger (Watson and Peniston 2018). Where do the billions of our taxpayer dollars go? To the world's most powerful military. And if you don't believe that the US military serves the interest of American empire, then I have some property in Florida that I would like to sell you. Are all these military operations executed 'purely' in the interest of freedom and democracy? Well, that question can only be sufficiently answered on a case-bycase basis. A major obstacle in recognizing the political interests of the US empire can be crystallized in the widespread belief that our military are God's Holy Warriors. Holy Warriors, yes. But God's Holy Warriors?

The haze of nebulosity surrounding the meaning of discipleship has created a void where fools rush in. Fools such as Donald Trump, just waiting to become divinized by the media apparatuses available to him. Having visited Israel on a number of occasions and given talks at Hebrew University of Jerusalem (as well as Birzeit University in the West Bank), and having visited Auschwitz, I am cautious about comparisons between Trump and Hitler, since I don't want to minimize the gravity of the crimes of the Third Reich or insult the memory of Holocaust victims. But I recall once reading in a newspaper article years ago that Trump kept Hitler's speeches on his bed table. Apparently, my recollection was correct. Burt Neuborne, a well-respected civil liberties lawyer, has recently published a book comparing the rhetorical character of Trump's speeches with those of Hitler, and the comparison is stunning. Included in Trump's first wife's divorce filings was a statement that Trump kept Hitler literature in a locked bedside cabinet that analyzed the rhetoric of Hitler's pre-World War Two speeches, and the impact of those speeches on the German population as a whole. In his new book, When at Times the Mob is Swayed: A Citizen's Guide to Defending Our Republic, Neuborne (2019) illustrates with granular insight and political verve how the US political system has up to this moment been unable to withstand the efforts by Trump to divide the country. Neuborne does not try to equate Hitler and Trump, which would be absurd at this particular conjuncture in US history. Putting migrant children in cages is horrible and unconscionable, but hardly the equivalent of exterminating 6 million Jews. Rather, Neuborne is concerned about whether or not the country can survive as a democracy in the face of another four years of Trump's Hitlerian rhetorical tropes and sinister political maneuvers designed to divide the country and create a cult following among his base (Rosenfeld 2019). Like Hitler, Trump enjoys mass rallies, expresses disgust towards ethnic minorities, gives the closing of borders pride of place in his political strategies, embraces detentions and deportations, utilizes economic protectionism, governs through corporate executives, weakens the power of labor unions, attacks the press as the enemy or the people (refuses to fly the flag at half-mast after the murder of five journalists in Annapolis, tries to block the merger of CNN's corporate parent, tries to revoke federal Postal Service contracts held by Amazon (because his critic, Jeff Bezos, owns Amazon), revokes the press credentials of a CNN reporter), creates his own media platform (by embracing alt-right media, and utilizing Fox News as the unofficial network of the Trumpian Republican Party), denigrates the judiciary and rule of law, engages in racially motivated attacks on immigrants and refugees, humiliates his political opponents, places women in secondary roles in the government, demands 
personal loyalty, divinizes the military, throws into the wind domestic democratic processes, and attacks the notion of objective truth and scientific expertise so that he can rule by populist fiat through spreading blatant lies through Twitter and yet remain unchallenged as a popular hero loved and adored by the masses, and where the masses - rather than the judicial system - can pass judgement on others. And where the mob can cry 'lock her up' and 'send her back' and beat up protesters, and where unstable adherents can join extremist white ethno-nationalist organizations to wreak more havoc in our country. It is precisely the technology of the times, where 8chan and 4chan can light up Trump's fascist rhetoric and where people can retreat into their social media caves to find relief and sustenance with their extremist group of choiceand there are an endless array, just check the archives of the Southern Poverty Law Center - and to have their hate amplified to whatever degree will enable Trump to continue his fascist crusade. In the face of this man, searching for a permanent balcony from which to jut his sweaty chin, can the Congress, the Electoral College, and the Supreme Court stop the defenestration of democracy? Do we shudder to come up with a halting response or do we take political action to build a socialist alternative to Trumpworld?

\section{References}

Baker, P., \& Vigdor, N. (2019). 'She's Not My Type': Accused Again of Sexual Assault, Trump Resorts to Old Insult. The New York Times, 24 June. https://www.nytimes.com/2019/06/24/us/politics/jean-carrolltrump.html. Accessed 11 August 2019.

BBC News (2019). Trump says sexual assault accuser E Jean Carroll 'not my type'. 25 June. https://www.bbc. com/news/world-us-canada-48754959. Accessed 11 August 2019.

Derrickson, S. (2008). The Day the earth stood still [Motion picture]. Los Angeles: Twentieth Century Fox, 3 Arts Entertainment, Dune Entertainment III, Earth Canada Productions, and Hammerhead Productions.

Drexler-Dreis, J. (2013). Interview with Jon Sobrino. Newsletter CLT 6 (September). https://theo.kuleuven. be/en/research/centres/centr_lib/interview-with-jon-sobrino.pdf. Accessed 28 August 2019.

Kubrick, S. (1968). 2001: a space odyssey [motion picture]. Los Angeles: Metro-Goldwyn-Mayer (MGM) and Stanley Kubrick Productions.

Lieb, M. (1998). Children of Ezekeil. Durham and London: Duke University Press.

Marx, K. (1843). A Contribution to the Critique of Hegel's Philosophy of Right. https://www.marxists. org/archive/marx/works/1843/critique-hpr/intro.htm. Accessed 28 August 2019.

McLaren, P. (2015). Pedagogy of insurrection: from resurrection to revolution. New York: Peter Lang.

McLaren, P., \& Jandrić, P. (2017). From liberation to salvation: revolutionary critical pedagogy meets liberation theology. Policy Futures in Education, 15(5), 620-652. https://doi.org/10.1177 /2F1478210317695713.

McLaren, P., \& Jandrić, P. (2018a). Paulo Freire and liberation theology: the Christian consciousness of critical pedagogy. Vierteljahresschrift für wissenschaftliche Pädagogik, 94(2), 246-264. https://doi.org/10.30965 /25890581-09402006.

McLaren, P., \& Jandrić, P. (2018b). Karl Marx and liberation theology: dialectical materialism and Christian spirituality in, against, and beyond contemporary capitalism. TripleC: Communication, Capitalism \& Critique, 16(2), 598-607. https://doi.org/10.31269/triplec.v16i2.965.

Naftali, T. (2019). Ronald Reagan's long-hidden racist conversation with Richard Nixon. The Atlantic, 30 July. https://www.theatlantic.com/ideas/archive/2019/07/ronald-reagans-racist-conversation-richardnixon/595102/. Accessed 11 August 2019.

Neuborne, B. (2019). When at Times the Mob is Swayed: A Citizen's Guide to Defending Our Republic. New York: The New Press.

Pitcavage, M. (2019). Murder and extremism in the United States in 2018. USA: anti-defamation league. https://www.adl.org/media/12480/download. Accessed 11 August 2019. 
Rosenfeld, S. (2019). Trump is copying Hitler's early rhetoric and policies in 20 different ways. RawStory, 9 August. https://www.rawstory.com/2019/08/trump-is-copying-hitlers-early-rhetoric-and-policies-in-20different-ways/. Accessed 28 August 2019.

Sakuma, A. (2019). Hate crimes reportedly jumped by 226 percent in counties that hosted Trump campaign rallies. The Vox, 24 March. https:/www.vox.com/2019/3/24/18279807/trump-hate-crimes-study-whitenationalism. Accessed 11 August 2019.

Savell, S., \& 5W Infographics (2019). This Map Shows Where in the World the U.S. Military Is Combatting Terrorism. Smithsonian Magazine, January. https://www.smithsonianmag.com/history/map-showsplaces-world-where-us-military-operates-180970997/. Accessed 29 August 2019.

Sadowski, D. (2019). Theologians examine role of power, clericalism in the sex abuse crisis. Crux, 31 March. https://cruxnow.com/church-in-the-usa/2019/03/31/theologians-examine-role-of-power-clericalism-inthe-sex-abuse-crisis/. Accessed 28 August 2019.

Viereck, G. S. (1929). What life means to Einstein. The Saturday Evening Post, 26 October. http://www. saturdayeveningpost.com/wp-content/uploads/satevepost/einstein.pdf. Accessed 28 August 2019.

Watson, B., \& Peniston, B. (2018). US at war in 7 countries — including Niger; US Army rebuilds Afghan firebases; F-35s to India?; and just a bit more... Defense One, 15 March. https://www.defenseone. com/news/2018/03/the-d-brief-march-15-2018/146688/. Accessed 28 August 2019.

Zuboff, S. (2019). The Age of Surveillance Capitalism: The Fight for a Human Future at the New Frontier of Power. New York: PublicAffairs. 